\title{
Infeksi penyakit kulit pada anak dan determinannya
}

\author{
Marlinang Isabella Silalahi ${ }^{1}$, Eva Ellya Sibagariang ${ }^{1 \star}$, Nanda Henrista ${ }^{1}$, Delores Elisabeth Sormin ${ }^{1}$, Evan \\ Kurniawan ${ }^{1}$, Wilsen $^{1}$ \\ ${ }^{1}$ Fakultas Kedokteran, Kedokteran Gigi dan Ilmu Kesehatan Universitas Prima Indonesia
}

\begin{abstract}
ABSTRAK
Penyakit kulit merupakan salah satu jenis penyakit yang sering ditemukan pada anak akibat kurang memperhatikan kebersihan diri dan sanitasi lingkungan. Tujuan penelitian ini adalah untuk menganalisis determinan infeksi penyakit kulit pada anak. Penelitian ini adalah penelitian kuantitatif dengan desain penelitian menggunakan rancangan cross sectional. Sampel penelitian berjumlah 62 orang. Data diuji secara statistik dengan menggunakan uji Chi Square. Hasil penelitian menunjukkan terdapat hubungan antara personal hygiene $(0,000)$ dan sanitasi lingkungan $(0,000)$ dengan kejadian infeksi penyakit kulit pada anak, Disarankan agar memperhatikan personal hygiene anak terutama dalam hal mencuci tangan dengan sabun dengan baik dan benar dan mengganti pakaian setelah mandi. Promosi kesehatan terutama yang berkaitan dengan masalah penyakit penyakit kulit infeksi perlu ditingkatkan agar masyarakat lebih peduli dengan risiko infeksi penyakit kulit.

Kata kunci : infeksi penyakit kulit, personal hygiene, sanitasi lingkungan, anak
\end{abstract}

Skin disease is one type of disease that is often found in children due to lack of attention to personal hygiene and environmental sanitation. The purpose of this study was to analyze the determinants of skin disease infection in children. This research is a quantitative research with a research design using a cross sectional design. The research sample amounted to 62 people. The data were tested statistically by using the Chi Square test. The results showed that there was a relationship between personal hygiene (0.000) and environmental sanitation (0.000) with the incidence of skin disease infections in children. It is recommended to pay attention to children's personal hygiene, especially in terms of washing hands with soap properly and properly and changing clothes after bathing. Health promotion, especially related to infectious skin diseases, needs to be improved so that people are more concerned with the risk of skin disease infections.

Keywords: skin disease infection, personal hygiene, environmental sanitation, children

*Alamat korespondensi: evasibagariang@yahoo.com

DOI: $10.34012 /$ jpms.v4i1.2373

\section{PENDAHULUAN}

Kulit merupakan organ tubuh pada manusia yang sangat penting karena terletak pada bagian luar tubuh yang berfungsi untuk menerima rangsangan seperti sentuhan, rasa sakit dan pengaruh lainnya dari luar. ${ }^{1}$ Adapun fungsi utama kulit adalah melindungi, absorpsi, ekskresi, persepsi, regulasi suhu tubuh, pembentukan vitamin D, dan keratinisasi. Begitu pentingnya kulit. Selain menjamin kelangsungan hidup juga mempunyai fungsi lain yaitu estetik (menyokong penampilan), ras, indikator sistemik, dan sarana komunikasi nonverbal antar individu. Kulit juga berfungsi sebagai pembungkus yang elastis yang dapat melindungi tubuh dari lingkungan terhadap penyakit. ${ }^{2}$

Penyakit kulit merupakan salah satu jenis penyakit yang sering ditemukan pada masyarakat akibat kurang memperhatikan kebersihan diri (personal hygiene) dan sanitasi lingkungan. Psoriasis, kusta atau hansen, dermatitis, scabies, panu, cacar dan lain-lain adalah beberapa jenis penyakit yang sering dialami masyarakat. Kulit yang paling sering atau umum ditemukan yaitu di antaranya abrasi atau hilangnya lapisan epidermis, kulit menjadi kasar, kering, bersisik dan biasanya berada pada area tangan dan kaki. ${ }^{3}$ 
Penyakit kulit dapat disebabkan oleh beberapa faktor seperti lingkungan dan kebiasaan sehari-sehari yang buruk, seperti perubahan iklim, virus, bakteri, alergi, daya tahan tubuh dan lain-lain. ${ }^{4}$

Kasus penyakit kulit yang dialami masyakat disebabkan oleh faktor sanitasi lingkungan dan kurang baiknya personal hygiene masyarakat yang baik. WHO mencatat angka kejadian skabies pada tahun 2014 sebanyak 130 juta jiwa orang di dunia. ${ }^{5}$ Penyakit kulit yang disebabkan oleh jamur merupakan infeksi yang paling sering terjadi pada bagian kulit menunjukan angka prevalensi $20-25 \%$ di seluruh dunia. ${ }^{6}$ Studi terdahulu menyimpulkan infeksi jamur merupakan penyakit kulit paling sering, diikuti oleh infestasi parasit. Infeksi jamur yang sering terjadi adalah pitiriasis versikolor, sedangkan infestasi parasit yang paling sering adalah skabies. ${ }^{7}$ Kepadatan penduduk, kondisi sosial ekonomi, lingkungan, malnutrisi dan lain-lain menjadi faktor resiko infeksi penyakit kulit pada anak. Anak sering terpajan kondisi yang menyebabkan lebih mudah terkena penyakit kulit, sebagai contoh faktor iklim misalnya suhu dan kelembaban yang menyebabkan kolonisasi bakteri atau jamur meningkat. ${ }^{8}$ Selain itu, rendahnya kesadaran mencuci tangan, praktek mandi yang kurang baik, menjaga kebersihan pakaian yang rendah dan rendahnya kesadaran untuk mengganti dan membersihkan sprei tempat tidur dalam jangka waktu tertentu. Rendahnya kesadaran tentang kebersihan diri dapat menyebabkan tubuh terserang berbagai penyakit seperti penyakit kulit maupun penyakit infeksi. ${ }^{9}$

Data Profil Kesehatan Indonesia tahun 2015 menunjukkan bahwa penyakit kulit dan jaringan subkutan menjadi peringkat ke tiga dari 10 penyakit terbanyak pada pasien rawat jalan di rumah sakit se-Indonesia berdasarkan jumlah kunjungan yaitu sebanyak 192.414 kunjungan, kunjungan kasus baru 122.076 kunjungan sedangkan kasus lama 70.338 kunjungan. ${ }^{10}$ Jumlah kasus penyakit kulit di Sumatera Utara adalah sebesar 14.415.391 kasus atau menyumbang 5,4 \% dari total kasus penyakit kulit di Indonesia. ${ }^{11}$ Berdasarkan hasil survei awal yang dilakukan di UPT Puskesmas Belawan, pada tahun 2016 jumlah penderita infeksi penyakit kulit sebanyak 796 kasus, akan tetapi pada tahun 2017 penyakit kulit mengalami penurunan sebanyak 694 kasus, sedangkan di tahun 2018 infeksi penyakit kulit kembali mengalami penurunan sebanyak 638 kasus. Pada tahun 2018, infeksi penyakit kulit merupakan salah satu dari 10 penyakit tertinggi di UPT Puskesmas Belawan. Penelitian ini bertujuan untuk menganalisis hubungan personal hygiene dan sanitasi lingkungan dengan kejadian penyakit kulit infeksi pada anak.

\section{METODE}

Jenis penelitian ini adalah survei analitik dengan rancangan cross-sectional study. Penelitian dilakukan di UPT Puskesmas Belawan mulai dari bulan September-Desember 2021. Populasi dalam penelitian ini sebanyak 160 orang tua yang mempunyai anak yang berusia 5-9 tahun. Teknik pengambilan sampel yang digunakan adalah simple random sampling. Sampel dalam penelitian ini adalah sebanyak 62 sampel. Pengumpulan data dilakukan dengan cara wawancara dengan menggunakan alat bantu kuesioner. Setelah data terkumpul kemudian dilakukan analisis data dengan menggunakan SPSS. Analisis data dalam penelitian ini ada 2 yaitu analisis univariat bertujuan untuk menghasilkan tabel distibusi dan persentase dari setiap variable dan analisis bivariat bertujuan untuk menghasilkan hasil uji apakah ada atau tidak hubungan variabel independen dengan variabel dependen dengan mengunakan uji Chi Square.

\section{HASIL}

Tabel 1 menunjukkan bahwa mayoritas umur orang tua anak adalah $<35$ tahun yaitu sebanyak 39 orang $(62,9 \%)$, mayoritas pendidikan terkhir orang tua anak adalah SMP yaitu sebanyak 26 orang (41,9\%), dan mayoritas jenis pekerjaan orang tua anak adalah IRT yaitu sebanyak 40 orang (64,5\%). Sedangkan mayoritas umur anak > 5 tahun sebanyak 54 orang (87,1\%). Berdasarkan personal hygiene, kebanyakan responden memiliki personal hygiene yang buruk $(61,3 \%)$. 
Dari tabel 2 memperlihatkan proporsi personal hygiene responden yang buruk sebanyak 24 orang yang mayoritas mengalami penyakit infeksi yaitu 16 orang $(66,7 \%)$ dan yang tidak mengalami penyakit infeksi yaitu 8 orang (33,3\%). Sedangkan personal hygiene yang baik sebanyak 38 orang yang mayoritas tidak mengalami infeksi penyakit kulit yaitu 33 orang $(86,8 \%)$ dan yang tidak mengalami penyakit infeksi yaitu 5 orang $(13,2 \%)$. Setelah dilakukan uji statistik didapatkan nilai $\mathrm{p}=0,000$. Dapat disimpulkan ada hubungan personal hygiene dengan kejadian infeksi penyakit kulit pada anak.

Responden dengan sanitasi lingkungan tidak memenuhi syarat sebanyak 26 orang yang mayoritas mengalami penyakit infeksi kulit yaitu 16 orang $(61,5 \%)$ dan yang tidak mengalami penyakit infeksi kulit yaitu 10 orang $(38,5 \%)$. Sedangkan sanitasi lingkungan responden yang memenuhi syarat sebanyak 36 orang, mayoritas tidak mengalami penyakit kulit yaitu 31 orang $(86,1 \%)$ dan yang mengalami infeksi penyakit kulit yaitu 5 orang $(13,9 \%)$. Dengan nilai $\mathrm{p}=0,000$ maka disimpulkan ada hubungan sanitasi lingkungan dengan kejadian infeksi penyakit kulit pada anak.

\begin{tabular}{|c|c|c|c|}
\hline \multirow{2}{*}{ Variabel } & \multicolumn{2}{|c|}{ Infeksi penyakit kulit } & \multirow[b]{2}{*}{$\mathrm{p}$} \\
\hline & Sakit & Sehat & \\
\hline \multicolumn{4}{|l|}{ Personal hygiene } \\
\hline Buruk & 16 & 8 & 0,000 \\
\hline Baik & 5 & 33 & \\
\hline \multicolumn{4}{|l|}{ Sanitasi lingkungan } \\
\hline Tidak memenuhi syarat & 16 & 10 & 0,000 \\
\hline Memenuhi syarat & 5 & 31 & \\
\hline
\end{tabular}

Tabel 1. Karakteristik responden $(n=62)$

\begin{tabular}{|c|c|c|}
\hline Karakteristik & Jumlah & Persentase \\
\hline \multicolumn{3}{|l|}{ Umur } \\
\hline$<35$ tahun & 39 & 62,9 \\
\hline$>35$ tahun & 23 & 37,1 \\
\hline \multicolumn{3}{|l|}{ Pendidikan } \\
\hline $\mathrm{SD}$ & 12 & 19,4 \\
\hline SMP & 26 & 41,9 \\
\hline SMA & 23 & 37,1 \\
\hline Sarjana & 1 & 1,6 \\
\hline \multicolumn{3}{|l|}{ Pekerjaan } \\
\hline Ibu rumah tangga & 40 & 64,5 \\
\hline Pegawai swasta & 1 & 1,6 \\
\hline Wirawasta & 7 & 11,3 \\
\hline Pedagang & 13 & 21 \\
\hline Nelayan & 1 & 1,6 \\
\hline \multicolumn{3}{|l|}{ Umur anak } \\
\hline$<5$ tahun & 3 & 12,9 \\
\hline$>5$ tahun & 9 & 87,1 \\
\hline \multicolumn{3}{|l|}{ Jenis kelamin anak } \\
\hline Laki-laki & 32 & 51,6 \\
\hline Perempuan & 30 & 48,4 \\
\hline \multicolumn{3}{|l|}{ Personal hygiene } \\
\hline Buruk & 24 & 38,7 \\
\hline Baik & 38 & 61,3 \\
\hline \multicolumn{3}{|l|}{ Sanitasi lingkungan } \\
\hline Tidak memenuhi syarat (TMS) & 26 & 41,9 \\
\hline Memenuhi syarat (MS) & 36 & 58,1 \\
\hline \multicolumn{3}{|l|}{ Infeksi penyakit kulit } \\
\hline Sakit & 21 & 33,9 \\
\hline Sehat & 41 & 66,1 \\
\hline
\end{tabular}

\section{PEMBAHASAN}

Salah satu faktor resiko gangguan kulit adalah kebersihan perorangan yang kurang baik. Dalam rangka memelihara kebersihan kulit, kebiasaan kebiasaan yang sehat. Harus diperhatikan seperti menjaga kebersihan pakaian, mandi secara teratur, mandi menggunakan air bersih dan sabun serta menjaga kebersihan lingkungan. ${ }^{12}$ Salah satu pencegahan gangguan kulit yang dapat dilakukan adalah menjaga kebersihan diri (personal hygiene). Kebersihan diri merupakan usaha dari individu atau kelompok dalam menjaga kesehatan melalui kebersihan individu dengan cara mengendalikan kondisi lingkungan dan gangguan terhadap kulit. ${ }^{13}$

Dari hasil penelitian diketahui bahwa masih banyak responden yang memiliki personal hygiene yang buruk. Personal hygiene yang buruk seperti mandi 1 kali dalam 1 hari, dan belum benar dalam mencuci tangan pakai sabun merupakan hal yang mendukung terjadinya penyakit kulit infeksi. Responden belum paham betul bagaimana cara mencuci tangan dengan sabun mengakibatkan responden hanya sekedar mencuci tangannya saja tanpa memperhatikan ketepatan dan keefektifannya. Tujuan utama mencuci tangan pakai sabun adalah untuk membunuh kuman/bakteri yang terdapat pada 
tangan namun akibat mencucui tangan yang hanya sekedarnya saja mengakibatkan bakteri atau kuman tersebut tidak mati dan hal ini dapat menginfeksi kulit. Dari penelitian diketahui bahwa masih banyak anak responden yang mandi dengan menggunakan sabun mand bersama hal ini dapat menjadi faktor pendukung terjadi nya penyakit kulit infeksi akibat dari penggunaan sabun yang telah terkontaminasi oleh berbagai zat atau mungkin mikroba patogen. Peneliti berasumsi bahwa semakin buruk personal Hygiene maka akan semakin tinggi resiko seseorang untuk terkena penyakit kulit. Hasil penelitian yang dilakukan oleh Sajida (2012) menunjukkan bahwa ada hubungan yang bermakna antara kebersihan kulit, kebersihan tangan dan kuku, kebersihan pakaian, kebersihan handuk, kebersihan tempat tidur dan sprei, kebersihan sanitasi lingkungan dengan keluhan penyakit kulit. ${ }^{12}$ Personal hygiene juga berhubungan dengan kejadian skabies. ${ }^{14}$ Penyakit kulit terjadi akibat kurang baiknya personal hygiene individu yaitu seperti tidak mencuci tangan dengan sabun, tidak membersihkan sela-sela jari dan tidak mandi minimal 2 kali dalam sehari. ${ }^{15}$

Sumber air juga merupakan salah satu faktor resiko kejadian penyakit kulit, sumber air yang sudah tercemar/terkontaminasi dapat meningkatkan resiko terjadinya penyakit kulit. Dari penelitian dilapangan diketahui sumber air masih buruk hal ini terjadi karena sumber air terkadang terkontaminasi oleh air laut, selain itu air yang digunakan responden juga berbau dan agak berwarna. Sumber air merupakan salah satu faktor resiko kejadian penyakit kulit, sumber air yang sudah tercemar/terkontaminasi dapat meningkatkan resiko terjadinya penyakit kulit. Penelitian yang dilakukan oleh Jesica dkk (2016) di Desa Kedungrandu merupakan wilayah Tempat Pembuangan Akhir Gunung Tugel terbesar di Bayumas menunjukkan bahwa ada hubungan jenis sumber air yang digunakan dengan kejadian penyakit kulit. ${ }^{16}$

Penelitian ini sejalan dengan penelitian yang dilakukan oleh Triani (2017) meneliti tentang hubungan antara kebersihan pribadi dan sanitasi lingkungan dengan kejadian skabies di Panti Asuhan Al Hidayah Mataram. Hasil wawancara dan observasi lingkungan sekitar panti asuhan didapatkan bahwa kondisi sanitasi lingkungan di Panti Asuhan Al Hidayah kurang sehat. Hal ini dapat diketahui dari pembuangan limbah baik mandi maupun cuci serta jamban dialirkan melalui sungai yang berada di samping dan belakang panti. Selain itu juga terdapat beberapa ruang kamar tidur yang ventilasinya sangat kurang, terlalu gelap dan sangat lembab. Dapat disimpulkan ada hubungan yang bermakna dari kejadian skabies dengan kebersihan pribadi, demikian juga antara sanitasi lingkungan dengan kejadian skabies didapatkan hubungan yang bermakna dengan nilai $\mathrm{p}=0,001 .{ }^{17}$ Demikian halnya dengan studi yang dilakukan oleh Mayrona (2018) yang meneliti tentang pengaruh sanitasi lingkungan terhadap prevalensi terjadinya penyakit skabies di Pondok Pesantren Matholiul Huda Al Kautsar Kabupaten Pati. Secara statistik ada pengaruh yang signifikan antara praktik kebersihan lingkungan dengan kejadian skabies. Santri yang praktik kebersihan lingkungannya yang buruk mempunyai resiko 1,4 kali untuk menderita kejadian skabies dibanding dengan santri yang praktik kebersihan lingkungannya baik. ${ }^{18}$

\section{KESIMPULAN}

Dari hasil analisis dapat disimpulkan bahwa personal hygiene dan sanitas lingkungan berhubungan dengan dengan kejadian infeksi penyakit kulit. Disarankan bagi masyarakat yang memiliki anak disarankan agar memperhatikan anak dalam personal hygiene anak terutama dalam hal mencuci tangan dengan sabun dengan baik dan benar dan personal hygiene mengganti pakaian setelah mandi. Promosi kesehatan terutama yang berkaitan dengan masalah penyakit penyakit kulit infeksi perlu ditingkatkan agar masyarakat lebih peduli dengan risiko infeksi penyakit kulit.

\section{REFERENSI}

1. Putri DD, Furqon MT, Perdana RS. Klasifikasi Penyakit Kulit Pada Manusia Menggunakan Metode Binary 
Decision Tree Support Vector Machine (BDTSVM) (Studi Kasus: Puskesmas Dinoyo Kota Malang). J Pengemb Teknol Inf dan Ilmu Komputer; Vol 2 No 5 [Internet]. 2018;2(5). Available from: https://jptiik.ub.ac.id/index.php/j-ptiik/article/view/1425

2. Wasitaatmadja S. Akne Vulgaris: Ilmu Penyakit Kulit dan Kelamin. 6th ed. Jakarta: Balai Penerbit FK UI; 2010.

3. Isro’in L, Andarmoyo S. L, Andarmoyo. Personal Hygiene. Yogyakarta: Graha Ilmu; 2012. Yogyakarta: Graha Ilmu; 2012.

4. Pardiansyah R. Association Between Personal Protective Equipment With Contact Dermatitis in Scavengers. J Major. 2015;4(4):1-8.

5. Wulandari A. Hubungan Personal Hygiene dan Sanitasi Lingkungan dengan Kejadian Skabies pada Santri di Pesantren Ulumul Qur'an Kecamatan Bebesen Kabupaten Aceh Tengah. J Sains. 2018;3(4):322-8.

6. Rizal AAF. Gambaran Tingkat Pengetahuan Remaja Putra Tentang Pencegahan Penyakit Kulit Di Pondok Pesantren Nabil Husein Samarinda. J Kesehat Masy Mulawarman. 2019;1(1):34.

7. Gustia R, Yenny SW, Octari S. Karakteristik penyakit kulit pada anak di poliklinik kulit dan kelamin RSUP Dr. M. Djamil Padang periode 2016-2018. J Kedokt Syiah Kuala. 2020;20(3):143-6.

8. Hogewoning AA, Koelemij I, Amoah AS, Bouwes Bavinck JN, Aryeetey Y, Hartgers F, et al. Prevalence and risk factors of inflammatory acne vulgaris in rural and urban Ghanaian schoolchildren. Br J Dermatol [Internet]. 2009 Aug 1;161(2):475-7. Available from: https://doi.org/10.1111/j.1365-2133.2009.09259.x

9. Noviya R. Buku Cerdik Penyakit-Penyakit Menular. Yogyakarta: Saufa; 2014.

10. Kementerian Kesehatan. Profil Kesehatan Indonesia Tahun 2015. Jakarta: Kementerian Kesehatan; 2016.

11. Kementerian Kesehatan. Profil Kesehatan Indonesia Tahun 2018. Jakarta: Kementerian Kesehatan; 2019.

12. Sajida A, Santi DN, Naria E. Hubungan Personal Hygiene dan Sanitasi Lingkungan dengan Keluhan Penyakit Kulit di Kelurahan Denai Kecamatan Medan Denai Kota Medan Tahun 2012. J Lingkung dan Kesehat Kerja. 2012;2(2):1-8.

13. Zakiudin A, Shaluhiyah Z. Perilaku Kebersihan Diri (Personal Hygiene) Santri di Pondok Pesantren Wilayah Kabupaten Brebes akan Terwujud Jika Didukung dengan Ketersediaan Sarana Prasarana. J Promosi Kesehat Indones [Internet]. 2016 Aug 18;11(2):64-83. Available from: https://ejournal.undip.ac.id/index.php/jpki/article/view/19004

14. Akmal SC, Semiarty R, Gayatri G. Hubungan Personal Hygiene Dengan Kejadian Skabies Di Pondok Pendidikan Islam Darul Ulum, Palarik Air Pacah, Kecamatan Koto Tangah Padang Tahun 2013. J Kesehat Andalas. 2013;2(3):164.

15. Zania E, Junaid, Ainurafiq. Faktor-Faktor yang Berhubungan dengan Kejadian Dermatitis Kontak pada Nelayan di Kelurahan Induha Kecamatan Latambaga Kabupaten Kolaka Tahun 2017. J Ilm Mhs Kesehat Masy. 2018;3(3):1-8.

16. Jesika P, Hilal N. Hubungan Jenis Sumber Air Dan Personal Hygiene Dengan Kejadian Penyakit Dermatitis Di Desa Kedungrandu Kecamatan Patikraja Kabupaten Banyumas Tahun 2016. Bul Keslingmas. 2017;36(4):494-500.

17. Triani E, Hidajat D, Setyorini RH, Cenderadewi M. Hubungan Kebersihan Pribadi dan Sanitasi Lingkungan dengan Kejadian Skabies pada Anak-anak di Panti Asuhan Al Hidayah Mataram. J Kedokt [Internet]. 2017;6(2):9-9. Available from: http://jku.unram.ac.id/article/view/124

18. Mayrona CT, Subchan P, Widodo A, Lingkungan S. Pengaruh Sanitasi Lingkungan Terhadap Prevalensi Terjadinya Penyakit Scabies Di Pondok Pesantren Matholiul Huda Al Kautsar Kabupaten Pati. Diponegoro Med J (Jurnal Kedokt Diponegoro). 2018;7(1):100-12. 